\title{
Escapes da retórica da objetividade nas fotografias do Jornal Zero Hora
}

\author{
Renata Lohmann' \\ Ana Taís Martins Portanova Barros ${ }^{2}$
}

\section{Resumo}

O presente artigo tem como objetivo estudar a questão da objetividade no fotojornalismo. Para tal, faz um estudo de como se dão os escapes da retórica da objetividade nas fotografias publicadas no jornal Zero Hora, de Porto Alegre, apresentando uma série de imagens veiculadas pelo periódico no ano de 2011. Apresenta conceitos de diversos autores como Roland Barthes, Arlindo Machado, Jacques Aumont e Philippe Dubois para averiguar o que seriam possíveis indicadores de conotação na fotografia.

Palavras-chave: fotografia; fotojornalismo; objetividade; comunicação.

\section{Resumen}

Este artículo tiene como objetivo estudiar la cuestión de la objetividad en el fotoperiodismo. Para ello, ha hecho un estudio de cómo ocurren fugas de la retórica de la objetividad en las fotografías publicadas en el diario Zero Hora, de Porto Alegre, con la presentación de una serie de imágenes publicadas por el periódico en 2011. Ofrece conceptos de diversos autores como Roland Barthes, Arlindo Machado, Jacques Aumont y Philippe Dubois para averiguar lo que sería posible indicadores de conotación sobre la foto.

Palabras clave: fotografía; fotoperiodismo; la objetividad; comunicación.

\begin{abstract}
This article aims to study the issue of objectivity in photojournalism. To do so, it studies how the leaks in the rhetoric of objectivity are given in the photographs published in the newspaper Zero Hora, of Porto Alegre, presenting a series of images published by the newspaper in 2011. It offers concepts of various authors such as Roland Barthes, Arlindo Machado, Jacques Aumont and Philippe Dubois to find out what would be possible connotation indicators on photography.
\end{abstract}

Keywords: photography; photojournalism; objectivity; communication.
${ }^{1}$ Bacharel em Comunicação Social - Jornalismo pela Universidade Federal do Rio Grande do Sul (2011) e mestre em Comunicação e Informação, com ênfase em

Cultura e Significação, pela mesma universidade (2015), atualmente é doutoranda na mesma área. É integrante do Grupo de Estudos de Comunicação e Imaginário (Imaginalis), sob orientação da Profa. Dra. Ana Taís Martins Portanova Barros. Possui vivência profissional em grandes empresas, como Grupo

RBS, Terra Networks e jornal O

Sul. Tem experiência nas áreas de jornalismo digital e fotografias digital e analógica. Suas áreas de interesse são: Comunicação, jornalismo imaginário, fotografia, estética e literatura.

${ }^{2}$ Ana Taís Martins Portanova BARROS é pós-doutora em Filosofia da Imagem pela Université Jean Moulin - Lyon/3 (2013), doutora em Ciências da Comunicação pela Universidade de São Paulo (2003), mestre em Ciências da Comunicação pela Universidade de São Paulo (1998) e bacharel em em Comunicação Social - Jornalismo pela Universidade Federal do Rio Grande do Sul (1992). Atuou como professora visitante do Master en Esthétique et Culture Visuelle da Universidade de Lyon III em 2013/2 junto à disciplina Acutalité de la Création et de la Recherche. Professora da pós-graduação em Comunicação e Informação e da graduação em Comunicação Social da Universidade Federal do Rio

Grande do Sul. Em 2008, fundou e lidera até hoje o Imaginalis - Grupo de Estudos sobre Comunicação 


\section{$Y_{\text {Rizoma }}$}

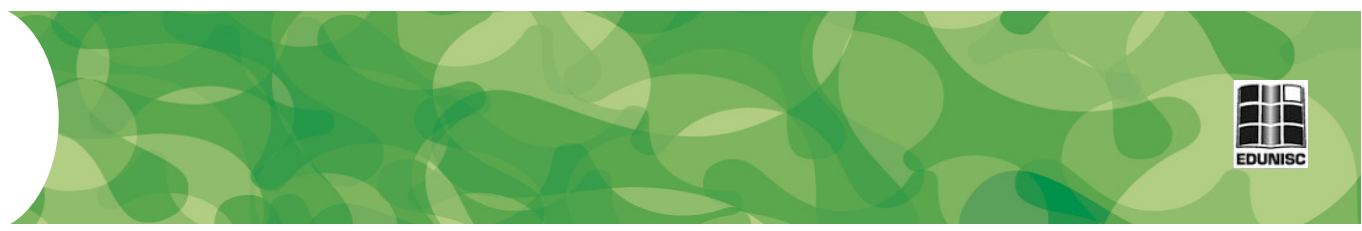

\section{Escapes da objetividade na fotografia}

A fotografia, desde seu surgimento, caminhou lado a lado com o jornalismo ${ }^{3}$. A partir de meados do século XIX, ela começou a ser utilizada em revistas ilustradas europeias, em virtude de seu valor informativo. A sensação inerente de realidade tornou a fotografia a forma de excelência da representação do homem moderno até o surgimento da televisão. Esta, tomando para si o espaço da primeira como melhor forma de representar o mundo, deixou para a fotografia o caminho aberto para o mundo das artes.

Conforme apresentamos em trabalho anterior (LOHMANN; BARROS, 2012), essa passagem de "espelho do real" para "forma de arte" foi uma longa caminhada e o leitor está cada vez mais consciente do papel ativo - e não passivo, como era visto pelo senso comum - que o fotógrafo exerce por trás das lentes.

Para a observação de padrões e características que denunciem a presença do fotógrafo por trás das lentes e os escapes da retórica da objetividade do fotojornalismo, analisamos 06 imagens do Jornal Zero Hora, sediado em Porto Alegre, no Rio Grande do Sul, do período de 1\%/08/2011 até31/10/2011. O critério utilizado para a composição do corpus foi de disponibilidade de material. As 06 imagens foram selecionadas através de uma leitura flutuante, um correr de olhos sobre as páginas do jornal buscando imagens que instantaneamente chamassem a atenção. Essa leitura flutuante poderia se assemelhar ao que Flusser (2002) denomina scanning. $\mathrm{O}$ autor afirma que através de um golpe de vista podemos captar o significado de uma imagem, mas que este método produz apenas um deciframento superficial do significado. Ele apresenta como solução para uma leitura aprofundada de uma imagem o método scanning, que é um vaguear do olhar pela imagem que proporciona a restituição das dimensões abstraídas. $\mathrm{O}$ scanning segue a estrutura da imagem, mas também os impulsos do observador, de forma que assim obtemos uma síntese entre as intencionalidades do emissor e do receptor. Durante o scanning, o olhar estabelece relações temporais entre os elementos da imagem, criando um tempo circular.

As fotografias selecionadas têm em comum o fato de questionarem, de forma sutil ou não, o padrão estético de objetividade que é esperado pelo senso comum. O conjunto de fotografias foi selecionado dentro do primeiro caderno de Zero Hora, excluindo os cadernos temáticos, sendo que nenhuma editoria específica foi selecionada e tanto fotos de agências de notícias quanto produções próprias dos fotógrafos de Zero Hora foram incluídas. Não foi feita nenhuma distinção entre fotolegendas e fotografias que acompanhavam reportagens, assim como também não foram excluídas fotografias de edições semanais ou de fim de semana. As únicas fotografias excluídas desta seleção foram as creditadas como divulgação.

A leitura flutuante também apontou os indicadores para as unidades de análise. Serão utilizados, concomitantemente, indicadores de conotação sugeridos por Barthes (1990), Machado (1984) e Aumont (1990).

Barthes (1990, p.15) elenca procedimentos de conotação que impõem um segundo sentido à mensagem fotográfica e que são elaborados nos diferentes e Imaginário / CNPq / UFRGS. Coordenadora do GT Imagem e Imaginários Midiáticos da Compós nos anos 2014/2015 e 2015/2016.

Editora da Intexto - Revista do Programa de Pós-Graduação em

Comunicação e Informação da Universidade Federal do Rio Grande do Sul. Assessora científica da FAPESP. Orientadora de doutorado e de mestrado acadêmico. Membro do comitê diretor do CRI2i (Centre de Recherches Internationales sur IImaginaire). Colunista mensal da Red Iberoamericana de Investigación en Imaginarios y Representaciones (https://imaginariosyrepresentaciones.wordpress.com).

3 Trabalho apresentado no GP Fotografia do XIV Encontro dos Grupos de Pesquisa em Comunicação, evento componente do XXXVII Congresso Brasileiro de Ciências da Comunicação. 
níveis de produção da fotografia. São seis as categorias: trucagem, pose, objetos, fotogenia, estetismo e sintaxe. O autor explica que toda imagem (aqui ele se refere a "artes" imitativas, como fotografia, desenhos, pintura, cinema e teatro) comportam duas mensagens, uma denotada, que é o próprio analogon, e outra conotada, que é a forma da sociedade de interpretá-la. Para Barthes (1990), esse código do sistema conotado é constituído por uma simbologia que é universal: retórica de época e estereótipos como esquemas, cores, grafismos e expressões. Por mais que a fotografia dê a sensação de ser um análogo do real, e portanto, que sua mensagem seria exclusivamente denotativa, essa concepção seria mítica, já que a fotografia jornalística é trabalhada, composta, escolhida dentro de padrões estéticos e ideológicos, e depois disso, ainda lida e consumida pelo público.

Atrucagem é uma intervenção no próprio plano de denotação da imagem. Utiliza-se da credibilidade do poder de denotação de uma fotografia para apresentar como denotada uma imagem que é conotada. É um procedimento no qual o fotógrafo aproxima artificialmente numa imagem duas outras que se encontravam distintas no ato da fotografia (uma pessoa posando em frente a um outdoor, por exemplo). As duas imagens separadas (a pessoa posando e a imagem presente no outdoor) têm um sentido quando isoladas, mas quando juntas em uma terceira imagem, numa montagem, assumem um novo sentido.

Na pose, a própria postura do modelo induz a leitura dos significados de conotação. Segundo Barthes (1990, p.16), “[...] a fotografia, evidentemente, só é significativa porque nela existe um conteúdo de atitudes estereotipadas que constituem elementos cristalizados de significação [...]".

Já os objetos possuem significados históricos e neste processo, o fotógrafo os valoriza na composição, ressaltando a sua presença e induzindo a geração de um sentido simbólico que pode até anular a primeira visão da fotografia, levando a associações de significações paralelas. Os objetos conduzem ao estabelecimento de relações entre ideias ou até verdadeiros símbolos.

$\mathrm{Na}$ fotogenia, a mensagem conotada está na própria imagem "embelezada". O fotógrafo usa recursos como enquadramento, iluminação, composição e velocidade do obturador.

No processo do estetismo, a fotografia se faz semelhante à pintura na sua composição ou substância visual. O fotógrafo se vale de recursos como cor, iluminação, textura, granulação, construindo assim imagens que remetem a arquétipos pictóricos, a grandes obras de arte.

Por fim, no processo da sintaxe, várias fotografias formam uma sequência de imagens e o significante de conotação não se encontra mais ao nível dos fragmentos, mas sim no encadeamento das imagens, formando uma narrativa, adquirindo assim, um sentido diferente do que na imagem fragmentada, sem sua sequência de ação.

É importante sublinhar que esses processos de conotação listados por Barthes (1990) não reduzem o que Dubois (1993) explica como uma sensação de realidade incontornável, da qual não nos desprendemos mesmo sabendo de todos os códigos envolvidos em sua produção. Isso torna necessária a utilização de alguns indicadores citados por Machado (1984), que promovem a percepção de uma construção subjetiva da imagem. 
O autor traz o tempo como outro aspecto a ser considerado na construção e leitura da fotografia. Em função da discrepância entre velocidade do obturador e velocidade do objeto fotografado, o fotógrafo pode se utilizar de imagens congeladas ou borradas para criar visões inéditas. Com velocidades instantâneas, paisagens plásticas que antes não eram aceitas passam a ser naturais, como pessoas congeladas no ar, em pleno movimento, ou ao contrário, borrões disformes sem nitidez. $\mathrm{O}$ autor afirma que os fotógrafos não sabem tirar proveito dos acidentes decorrentes dessas discrepâncias:

\begin{abstract}
A verdade é que o grosso da produção fotográfica convencional, embriagada de ilusão homológica, costuma rejeitar todos esses acidentes do acaso que fazem aflorar uma paisagem bizarra, preferindo apoiarse nos métodos elegantes da pintura figurativa [...]. É que o acidente, longe de encarnar a prova de uma objetividade "ontológica" do processo fotográfico, costuma desarticular o real ao invés de promovê-lo, pelo menos um certo estereótipo do "real" que é aquele que nos viciou a tradição figurativa. (MACHADO, 1984, p. 49).
\end{abstract}

Dubois (1993) também tem algo a acrescentar sobre o tempo, que corre em fluxo contínuo e infinito, porém, a fotografia detém esse fluxo com o corte abrupto do obturador, dessa forma, prendendo a imagem em uma espécie de limbo que ele se refere como fora do tempo. Para o pesquisador, a questão do gesto do corte é fundamental, é o movimento que ao mesmo tempo corta espacial e temporalmente a fotografia, tornando-a uma fatia única do espaço-tempo, um corte ao vivo. Ele lembra a importante diferença do tempo entre uma pintura e uma fotografia: enquanto a pintura é produzida lentamente, traço por traço, criada e recriada na mente do artista a cada instante, a fotografia é feita nesse único gesto de corte, independente da duração da exposição do fotograma, e que o golpe do corte é irremediável. Todo o fluxo do tempo é reduzido a um único ponto, que na imagem perdura e se repete em uma eternidade.

Outras questões importantes para Machado (1984) são a perspectiva e o enquadramento, visão partilhada por Aumont (1990). Machado (1984) fala da perspectiva artificialis e sua relevância para os pintores do Renascimento. Ela era vista como um sistema de representação "objetivo" e "científico", e desta forma, completamente fiel ao espaço real. Isto porque, segundo Machado

[...] procurava obter uma sugestão ilusionista de profundidade com base nas leis "objetivas" do espaço formuladas pela geometria euclidiana. No caso, o suporte matemático parecia dar garantias de racionalidade as suas projeções gráficas. (MACHADO, 1984, p. 63).

Ageometriaperspectivaéentãoumaformadeprojetaroespaçotridimensional em um espaço bidimensional, no caso, uma superfície plana que é a fotografia, e isso se faz através de certas regras a fim de conseguir transmitir de forma correta a noção de volumes e disposições espaciais. Com a criação da câmara obscura e, posteriormente, do mecanismo óptico da câmera fotográfica, que surgiram para resolver o problema da obtenção automática da perspectiva artificialis, a fotografia em si se torna indissociável dessa ideia de técnica de projeção. Como afirma Machado (1984, p. 65), "ao incorporar nos seus procedimentos ópticos 


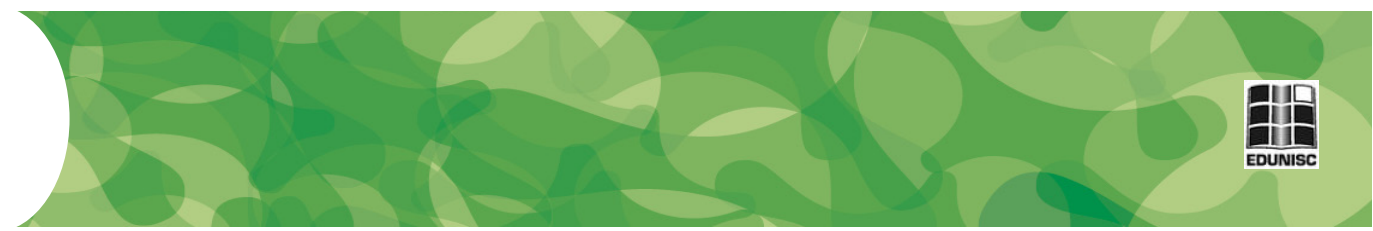

esse código perspectivo particular, o aparelho fotográfico buscava justamente perpetuar a impressão de "realidade" que está a ele associado". A perspectiva artificialis faz, na verdade, da visão humana, uma regra de representação. Num momento em que a pintura começava a explorar novas perspectivas em que o homem não é mais o centro de tudo, a fotografia surge trazendo de volta um sistema de representação burguês. Sobre ponto de vista, Machado afirma que é da mesma natureza ideológica que o recorte do enquadramento, já que o fotógrafo se posiciona em determinado ponto, estabelecendo na forma da perspectiva de sua visão uma hierarquia de valores dentro do enquadramento, colocando objetos em primeiro, segundo, terceiro plano etc.

Aumont (1990) conta que a crise da perspectiva na cultura moderna se relaciona a novas concepções de espaço, que surgem com a teoria da relatividade e as geometrias não-euclidianas e que influenciam tanto a arte, como a filosofia e toda a forma de pensamento. Insiste que considerar o olho humano como modelo e padrão de visão é uma ideologia, apesar de parecer natural.

Sobre o enquadramento (e neste quesito também incluímos ponto de vista, ângulo de tomada e o extraquadro), Machado (1984) afirma que toda a fotografia é um recorte do visível, selecionando um campo e descartando outro. É um processo classificatório que deixa na escuridão tudo aquilo que não convém aos interesses da enunciação, relegando ao extraquadro. Para Aumont (1990), além disso, enquadramento também tem a ver com a composição da imagem. Para Machado (1984), é importante que a imagem se deixe permear pelas marcas de existência da câmera e de um fotógrafo. Isso permite a percepção de um mecanismo enunciador, libertando a fotografia do fetiche do extraquadro e se abrindo para a compreensão do próprio trabalho produtor de signos. Ele afirma que toda a visão pictórica, mesmo a mais realista, não deixa de ser um processo classificatório, selecionando determinadas informações para ficarem à mostra, relegando outras ao extraquadro, e isso já enuncia uma intencionalidade. Ele, assim como os outros autores mencionados, fala da importância do que não é mostrado na imagem, que o extraquadro aponta para uma continuidade e a "simulação de um espaço infinito", escondendo assim sua própria precariedade e fragmentação.

Dubois (1993) considera que o espaço fotográfico não é determinado ou construído, mas que é capturado ou subtraído como um bloco. O fotógrafo, diferentemente de um pintor, não pode preencher lentamente seu espaço; o faz de uma única vez, extraindo um bloco do contínuo do tempo e espaço. Esse corte evidencia que este bloco pertencia a um conjunto maior, que ficou renegado a extraquadro. Para Dubois (1993), o extraquadro, o que a fotografia não mostra, é tão importante para a definição do espaço quando o que está no quadro. Essa relação da existência inevitável de uma realidade "virtual" fora das margens da imagem é marcada de várias formas por sua contiguidade física com o espaço inscrito na fotografia. Uma das formas que Dubois (1993) acredita indicar o extraquadro são os indicadores de movimento e deslocamento, quando a imagem fica absolutamente congelada, e os movimentos ficam presos em posições que o olho humano sequer seria capaz de captar, ou os movimentos fluídos, onde os objetos deixam apenas traços, vestígios e borrões de sua presença no quadro. Para Dubois (1993), esse extraquadro coloca fora do campo o próprio tempo 


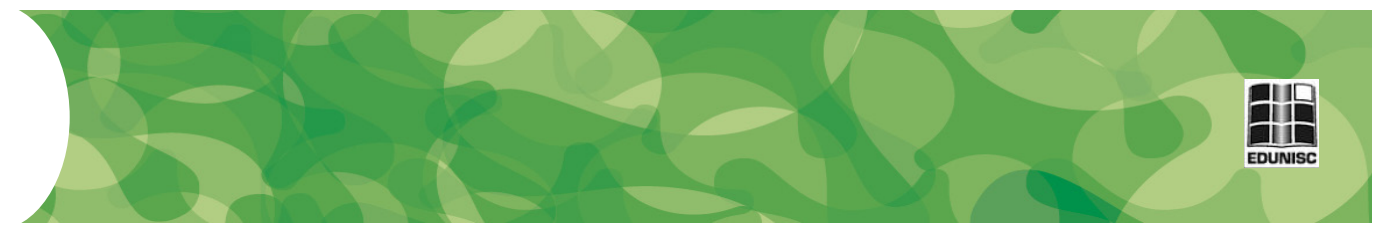

(sua duração crônica). Outro índice de extraquadro são os chamado jogos de olhar, onde o fotografado pode olhar em direção da câmera, por exemplo, e denunciar a presença do fotógrafo, ou olhar as margens, indicando a presença de outras coisas que foram subtraídas da imagem. $\mathrm{O}$ último indicador listado por Dubois (1993) é o chamado cenário, onde portas, janelas, molduras, quadros e espelhos indicam a presença de fragmentos de outros espaços contíguos ou exteriores ao principal, quebrando, assim, a visão plana do aparelho e mostrando uma multiplicação dos recortes. Os jogos com espelhos são os mais fascinantes representantes desse indicador, já que podem não apenas apresentar um ângulo novo de algo já presente na imagem, mas, muito além disso, introduzir na imagem algo que permanecia apenas como virtual, como possibilidade, e estava completamente fora do quadro. Todavia, os espelhos não deixam de ocultar com sua opacidade um pedaço do que estava por trás dele.

Sobre composição, Dubois (1993) também acrescenta que é a articulação entre o espaço representado e o espaço de representação, e que a organização e disposição dos objetos e proporções dependem de valores plásticos complexos e culturais. Além disso, questões como a homologia de estrutura (a exigência de que o horizonte na imagem seja horizontal ou torres sejam verticais, sempre levando em consideração as estruturas de forma como o homem de pé as vê) são importantes para a compreensão do espaço representado.

Por último, temos a questão da profundidade de campo e do foco. Lembrando a perspectiva artificialis, é sabido que a fotografia é utilizada para simular uma continuidade absoluta no espaço, do seu primeiro plano até o ponto de fuga. $\mathrm{O}$ foco é um dos fatores que pode causar uma ruptura na profundidade de campo, impondo uma leitura da foto, um ponto de atenção privilegiado hierarquicamente.

Com base nos quesitos apontados acima, as imagens serão analisadas para apontar como as diferentes técnicas foram utilizadas para quebrar o paradigma da objetividade ontológica no fotojornalismo. Para estudar o corpo empírico, um protocolo de análise foi formulado contendo os indicadores de conotação de Barthes (1990) e os indicadores de construção de subjetividade de Machado (1984), Dubois (1993) e Aumont (1990). Cada fotografia será analisada separadamente considerando os indicadores: trucagem, pose, objetos, fotogenia, estetismo, sintaxe, tempo, perspectiva, enquadramento e profundidade de campo. Com base nas análises realizadas, os dados serão interpretados a fim de indicar os procedimentos e efeitos de subjetividade no fotojornalismo do jornal Zero Hora.

É importante ressaltar que o debate sobre objetividade e subjetividade no jornalismo, e consequentemente, no fotojornalismo, permanece. Traquina (2004), partindo da visão do jornalismo de forma geral, afirma que a objetividade seria uma série de procedimentos que garantiriam a credibilidade do trabalho jornalístico, concedendo proteção contra eventuais críticas e dando legitimidade ao trabalho. A noção de imparcialidade faz parte desses mecanismos e posturas profissionais. $\mathrm{O}$ autor aponta, no entanto, que a complexa discussão sobre a objetividade no jornalismo não pode ser reduzida a simples dicotomia entre subjetividade e objetividade, afirmando que o conceito dessa última não surgiu como negação da primeira, mas como reconhecimento de sua inevitabilidade. 
A fotografia é um mundo ambíguo: apesar de ser evidência de alguma coisa, o fotógrafo trabalha na construção de seu significado por meio de uma série de escolhas, desde o aparato técnico até a pósprodução, título e legenda. Oliveira e Vicentini (2009), nesse aspecto, trazem três questões importantes concernentes à ética que devem ser levadas em consideração: quanto a manipulação da imagem aproxima ou afasta da realidade que se quer mostrar; quanto essa realidade que se quer mostrar se aproxima ou afasta do real; e quanto o real está a serviço de quem fotografa.

Compartilha-se uma visão de que a fotografia jornalística deve ser resultado da não-interferência do fotógrafo na cena, ao mesmo tempo em que ele [o fotógrafo] é tolerado. Não se leva em consideração que a realidade captada pela câmera já foi mediada pela própria percepção do fotógrafo, antes de ele disparar o obturador. (OLIVEIRA; VICENTINI, 2009, p. 117).

Essas questões serão levadas em consideração durante a análise de nosso corpus de fotografias e possíveis conclusões.

\section{Análise das fotografias}

\section{Figura 1:}

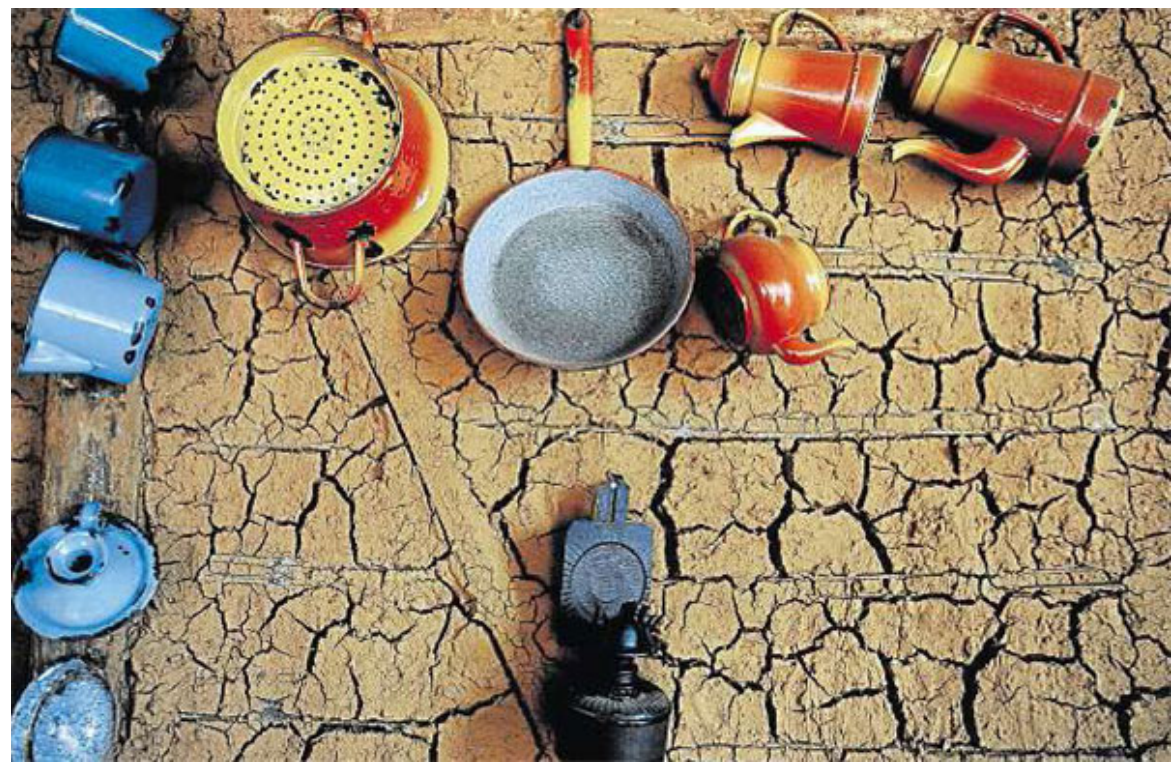

VIEIRA, M. [Sem título]. Zero Hora, Porto Alegre, 18 set. 2011. Contracapa. p. 40.1 fot., cor.

Legenda: No telhado de capim santa-fé, nas paredes de barro e nos velhos utensílios pendurados, o piquete Laços de Sangue, um dos mais visitados do Acampamento Farroupilha, reproduz a arquitetura rústica e o modo de vida do passado campeiro 


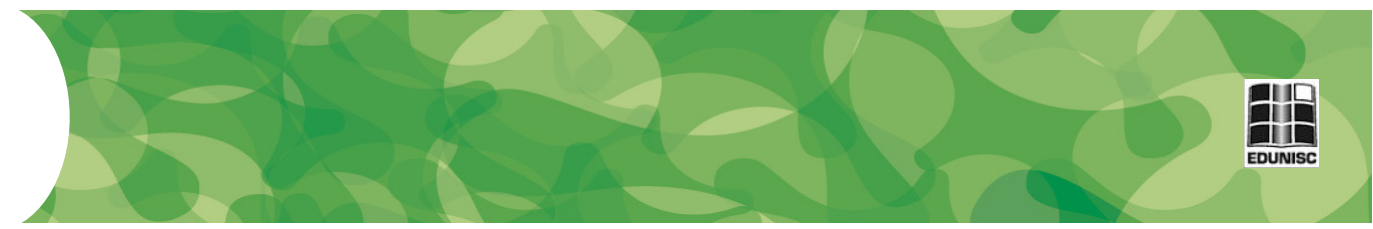

Os objetos são o ponto mais importante desta fotografia. São utensílios de cozinha, canecas, escorredor, frigideira, todos de metal, desgastados pelo tempo e pelo uso. A composição fotogênica destes objetos é única: todas as pequenas canecas, em tons de azul, estão enfileiradas à extrema esquerda na imagem; já os objetos maiores, todos em tons de laranja (oposto do azul na escala de cores) estão enfileirados na parte superior da imagem; absolutamente isolado de todos, está o pequeno fogareiro, que se encontra na linha diagonal de uma das ripas de madeira que compõem o fundo. Na questão do estetismo, o fundo da imagem se destaca: o suporte para todos estes objetos é uma parede de terra seca, com textura craquelada, atravessada por várias faixas de madeira na horizontal, além de uma vertical e uma diagonal. Todas essas faixas seguem a mesma direção que a composição dos objetos.

Por último, o enquadramento, que, por ser mais fechado, nos priva de uma contextualização do ambiente em que nos encontramos. É possível se ter uma noção apenas pelo estilo dos objetos e pelas condições da parede que os suporta, deixando-nos à mercê de todo o tipo de dúvidas e conjecturas.

\section{Figura 2:}

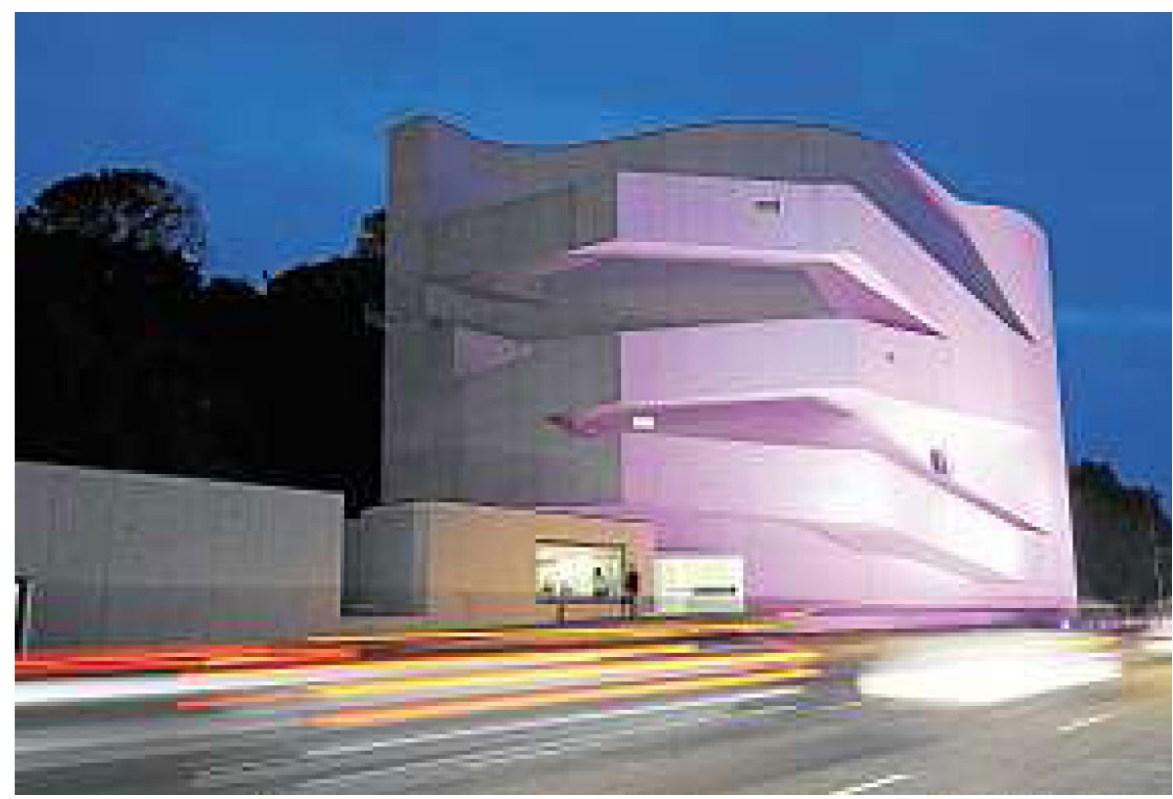

FRANCIOSI, A. [Sem título]. Zero Hora, Porto Alegre, 13 out. 2011. Primeiro Caderno, Geral. p. 37.1 fot., cor.

Legenda: Fachada da Fundação Iberê Camargo ficará iluminada até amanhã

Nesta fotografia de Adriana Franciosi, a questão do tempo é a mais importante. O tema da imagem era a iluminação especial da fachada da Fundação Iberê Camargo, logo, uma exposição um pouco mais prolongada da fotografia se fez necessária. Desta forma, foi possível atingir na imagem o tom marcante de rosa que iluminou o prédio, 
naturalmente da cor do concreto. Sem este tom de rosa, a estrutura do prédio ficaria muito semelhante à do asfalto, que se encontra na parte inferior do enquadramento.

Outra consequência importante, e a que mais nos evidencia a questão do tempo, é o traçado luminoso dos faróis dos veículos na avenida em frente ao prédio. Marcados como meteoros, eles deixam claro que esta imagem não foi feita em um instante, mas sim em um momento de tempo mais longo, já que foi possível conseguir um traçado de luz desenhado na imagem. $\mathrm{O}$ olho humano não é capaz visualizar a luz naturalmente dessa forma, logo, torna-se evidente que o tempo de exposição da fotografia foi uma escolha do fotógrafo para criar um efeito visual. O resultado estético dessa longa abertura do obturador também pode ser considerado como fotogenia.

Por último, temos o enquadramento da imagem. Fugindo do centralizado, a estrutura do prédio está ligeiramente à direita na fotografia, na parte superior, dando desequilíbrio à composição. $\mathrm{O}$ traçado de luz dos faróis ajuda a dar dinâmica à imagem, desta forma, fazendo com que o olhar corra como que em um trilho, seguindo do fora de quadro até atingir o prédio, que é o assunto principal. $\mathrm{O}$ fato de a avenida estar na diagonal na parte inferior da imagem também ajuda nessa sensação de movimento.

Figura 3:

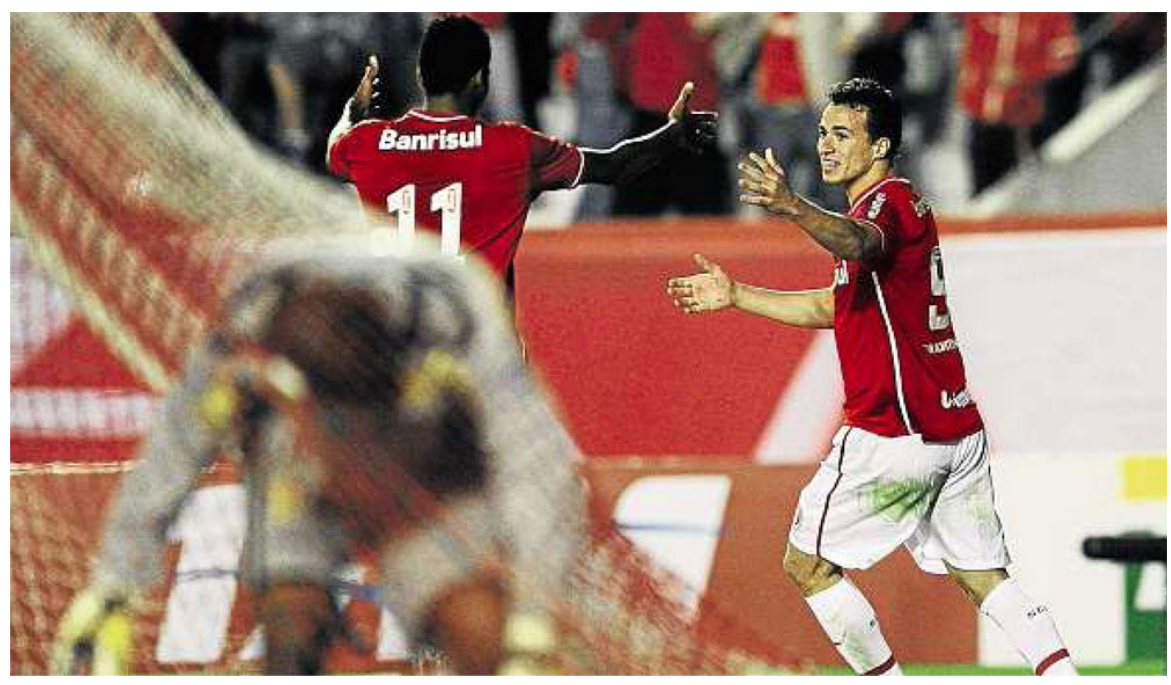

VARA, D. [Sem título]. Zero Hora, Porto Alegre, 18 ago. 2011. Capa. p. 01.1 fot., cor.

Legenda: Inter venceu o Botafogo por 1 a 0 no Beira-Rio, graças a gol do centroavante (D), o sétimo dele neste Brasileirão

A pose poderia ser considerada o elemento proeminente nesta imagem de Diego Vara: os jogadores do Internacional, que acabaram de marcar um gol, comemoram, um olhando para o outro, braços abertos e receptivos; o goleiro do time adversário está de joelhos no chão, rosto abaixado 
e escondido, pose abatida, e é engolido pela rede da goleira. Apesar de a interação entre os jogadores e da atitude do goleiro do time rival, a imagem não se trata de uma encenação, mas de um momento espontâneo entre os jogadores, não consistindo numa atitude estereotipada conforme definido por Barthes (1990).

O foco, no entanto, tem papel muito importante nessa fotografia. Enquanto os vencedores estão completamente focados, o goleiro vira um borrão sem linhas nítidas, assim como a torcida ao fundo, sendo realmente distinguível três substratos de foco na imagem separados entre si, quebrando a perspectiva da imagem, já que perdemos a sensação de fundo infinito.

O enquadramento também é um fator de conotação: na composição da imagem o goleiro ocupa quase toda a diagonal inferior esquerda, tapando inclusive metade do jogador que participou da jogada do gol. O jogador que fez o gol, porém, aparece por inteiro na imagem. A torcida foi registrada apenas do pescoço para baixo, permanecendo anônima na massa de pernas, troncos e braços.

\section{Figura 4:}

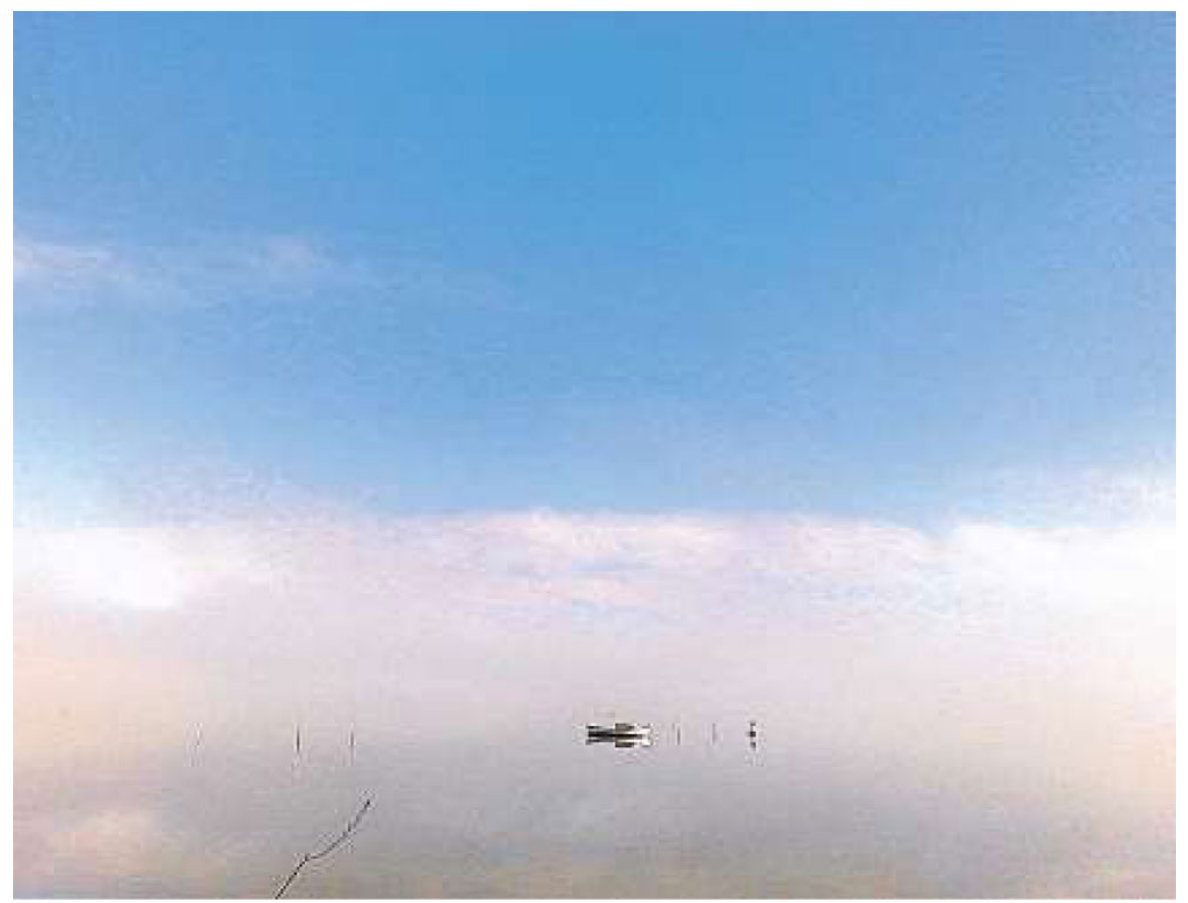

DIVÉRIO, R. [Sem título]. Zero Hora, Porto Alegre, 07 out. 2011. Geral. p. 29. 1 fot., cor.

Legenda: Antes de mudança no tempo, nevoeiro cobriu na manhã de ontem a Lagoa do Patos, em Rio Grande

A fotografia de Rafael Divério é complexa de compreender à primeira vista; numa passada rápida de olhos, pode parecer apenas céu e nuvens. A legenda ajuda a entender, trata-se de um nevoeiro na Lagoa dos Patos. Essa dificuldade se dá pela falta de pontos de referência: há apenas o barco no 
centro da foto, mas ele está distante e não é tão simples reconhecê-lo como tal. O nevoeiro é refletido nas águas, assim como as nuvens, parecendo uma continuidade: a imagem fica dividida, metade nuvens, metade céu. Esses aspecto nos levam ao enquadramento, mas também ao estetismo, já que a imagem parece uma pintura impressionista.

Como a linha do horizonte não é aparente, graças ao nevoeiro e o reflexo na água, ficamos sem noção de perspectiva e também de profundidade de campo. A fotografia poderia tanto ter um fundo infinito quanto ser completamente achatada, já que não somos capazes de perceber sua profundidade.

Figura 5:

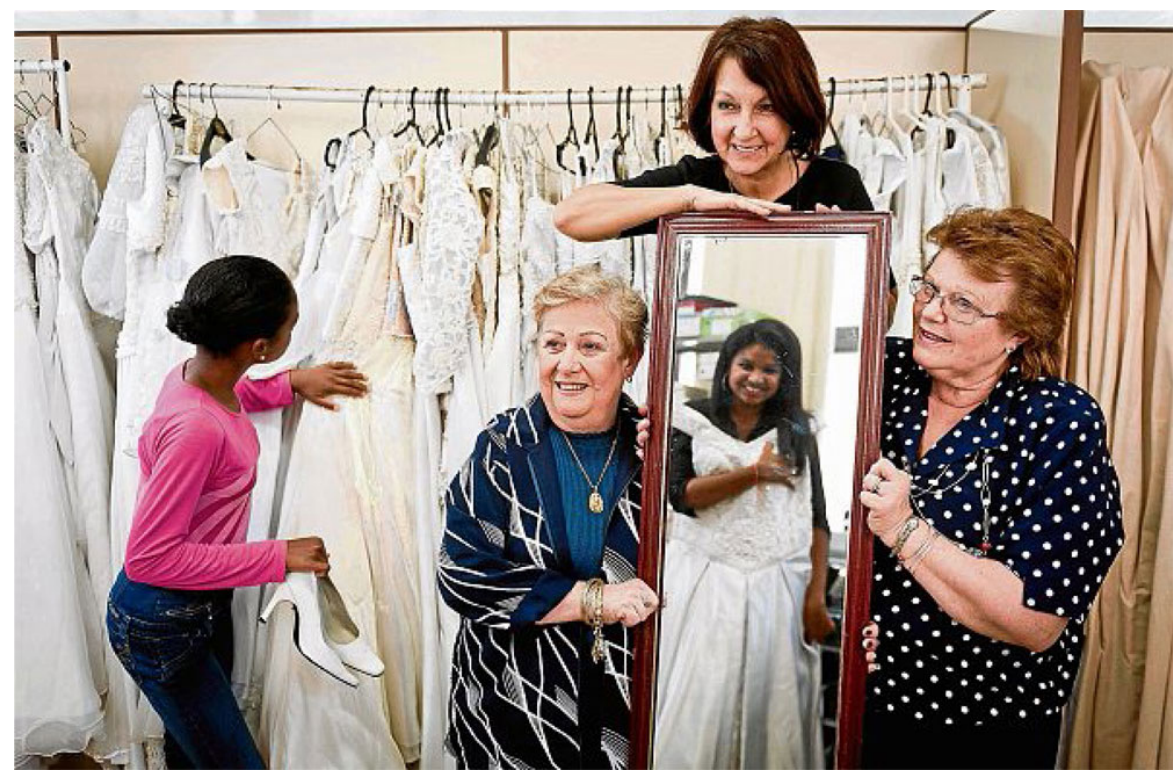

BRUXEL, M. [Sem título]. Zero Hora, Porto Alegre, 18 out. 2011. Contracapa. p. 56.1 fot., cor.

Legenda: Escolhidas pelo seu bom rendimento escolar, 17 garotas de comunidades pobres da Capital terão uma noite especial na próxima sextafeira, quando serão a atração principal de um baile de debutantes promovido por entidades beneficentes

$\mathrm{Na}$ fotografia de Mateus Bruxel, uma questão importante do enquadramento é trazida à tona: o fora-de-campo. A debutante, que é o tema principal na imagem, se encontra espacialmente fora da cena enquadrada pelo fotógrafo; no entanto, está presente da imagem através de seu reflexo em um espelho. Esta é uma forma de brincar com a noção de realidade. O olhar das três senhoras evidencia esse jogo de fora-de-campo/enquadramento: espacialmente elas dirigem seus olhares para a debutante, que na fotografia se encontra no espelho que elas mesmas seguram, o que torna esse jogo de olhares e espelho ainda mais potente, uma vez que a debutante encara a lente do fotógrafo através do espelho. 
Com o espelho, temos a multiplicação de olhares. O que antes era apenas uma realidade virtual, extirpada pelo recorte do enquadramento e apenas imaginada por quem observa a fotografia, agora pode ser visualizada através de um espelho. O plano único concebido pela câmera fotográfica é quebrado. Isso torna evidente que a fotografia é um recorte, uma escolha de visão do mundo, e não o mundo em si.

\section{Figura 6:}
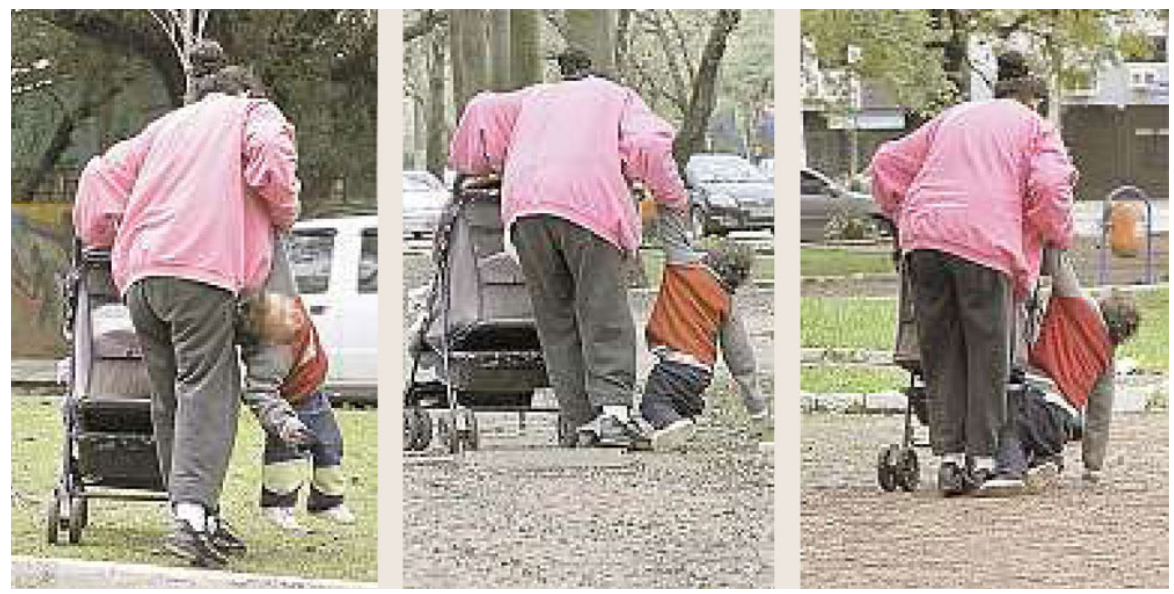

TRINDADE, T., ESPECIAL [Sem título]. Zero Hora, Porto Alegre, 02 ago. 2011. Informe especial. p. 03.1 fot., cor.

Legenda: Informe Especial só pode lamentar. As cenas ao lado foram flagradas ontem à tarde por um fotógrafo freelancer na Praça Garibaldi, em Porto Alegre. É triste saber que elas ainda sejam registradas em 2011. Empurrando um carrinho com um bebê, a mãe arrastava o outro filho, de pouco mais de um ano, pelo braço. Alertados, policiais conduziram todos ao Conselho Tutelar.

A sintaxe é um indicador de conotação que serve para nos trazer um conhecimento sobre o fato que não seria possível através de apenas uma imagem. Esta série de Tiago Trindade faz justamente isso: apenas uma das fotografias isoladas poderia nos dar a entender que a mãe estava segurando o filho para que não caísse no chão, ou para ajudá-lo a caminhar. Com a sequência de imagens, podemos notar que não é este o caso.

Uma série de imagens paradas denuncia a subjetividade porque não é assim que vemos o mundo, como uma história em quadrinhos. Nossa visão do mundo é de continuidade, e não um quadro-a-quadro. As imagens em série nos fazem perceber que alguém foi veloz o suficiente para registrar o desenrolar da ação, muito embora a sensação de testemunho permaneça. O ângulo da foto também é relevante, já que tirando a fotografia pelas costas do fotografado, pode-se proteger o rosto de identificação. 


\section{Conclusões primeiras}

Parece-nos que os escapes da retórica da objetividade no fotojornalismo de Zero Hora não se evidenciam por efeitos mirabolantes, manipulações em programas de edição de imagem, fotomontagem e afins, mas sim por recursos técnicos simples e discretos. São recursos básicos que qualquer equipamento fotográfico possui, não são necessárias lentes olho-de-peixe, flashes coloridos, iluminações excêntricas; apenas controle de obturador, diafragma, foco e um olhar apurado.

Podemos deduzir que os processos de conotação e quebra da objetividade não são decorrentes de uma tecnologia avançada, com o intuito de enganar o leitor, mas sim do olhar do fotógrafo, sua visão do mundo. Dentre os processos mais recorrentes, fotogenia, perspectiva, enquadramento e profundidade de campo, apenas a fotogenia pode ser feita através do computador, como recortar alguma imagem já pronta, alterar a saturação ou utilizar programas de edição para melhorar contraste ou retirar "defeitos". Apesar disso, ela também pode ser feita com a própria câmera, ao escolher uma composição inusitada, um tempo de exposição longo, ou uma cena com luz muito contrastada. $\mathrm{O}$ restante dos procedimentos apontados pelos indicadores são todos feitos durante a captação da imagem, e são notavelmente simples do ponto de vista técnico: escolher um determinado ponto de foco, um determinado enquadramento, um ponto de vista, uma perspectiva. Todos eles dependem do fotógrafo no momento do disparo da máquina fotográfica. Eles são frutos do olhar do fotógrafo, como autor, membro participante do processo. O fotógrafo não só observa a cena passivamente; ele é ativo, projeta através da fotografia sua visão de mundo.

O que o fotógrafo é, pensa e sente refletem na sua obra: sua visão política, sua fé, assim como o que vê como sendo relevante se mostram através de suas escolhas. É a forma como inclui ou exclui alguma figura no enquadramento, a forma como destaca ou tira importância de algo através do foco, a forma como ele espera, como uma tocaia, o momento ideal para congelar uma pose ou como deixa o momento fluir através da lente. Dubois (1993) afirma que não é mais possível pensar na fotografia fora do seu ato criador; a fotografia não pode ser vista como o produto de uma gama de técnicas, mas sim resultado de um ato icônico, algo que não pode ser concebido fora de suas circunstâncias criadoras.

Os escapes da retórica da objetividade no fotojornalismo se dão quando os elementos indicadores estão presentes e não há uma tentativa de escondê-los. Por isso, a leitura flutuante foi tão importante: através dela foi possível encontrar facilmente fotografias que eram diferentes, marcantes, que traziam inquietude. Através delas, o leitor do jornal se sente no papel de questionar onde o fotógrafo estava, o que mais havia além da moldura da fotografia, por que ele fez a fotografia de determinada forma.

Analisando as imagens do jornal Zero Hora, pudemos ver uma 

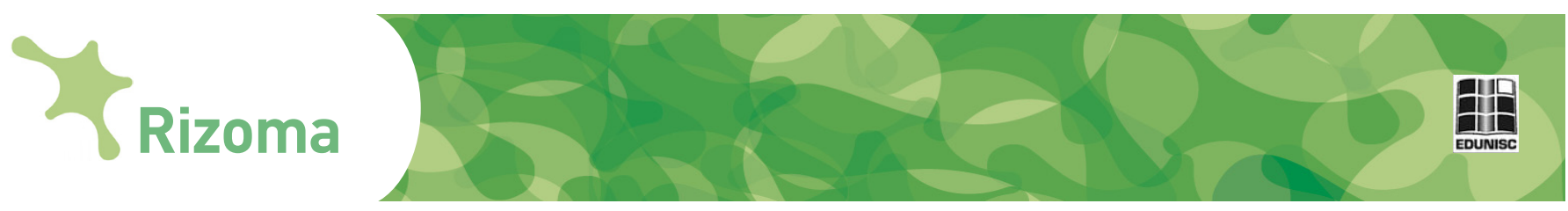

constante busca de imagens "fora do comum": não existe mais a preocupação de apenas ter uma foto para preencher espaço nas páginas do jornal e comprovar o ocorrido; busca-se uma diferenciação na produção fotográfica que vá muito além do esperado pelo leitor; imagens que não tragam apenas o valor do "isso aconteceu", "nós estivemos lá", mas fotografias esteticamente apuradas, técnicas inovadoras e ângulos diferentes dos concorrentes.

As imagens analisadas também mostram que a subjetividade não se dá através de nenhuma técnica absurdamente complexa, nem equipamentos muito tecnológicos. $\mathrm{Na}$ era digital, os limites do que é aceitável ou não na hora de editar uma imagem começam a ficar difusos. Nenhuma das imagens selecionadas nos três meses de observação se utilizou de trucagem, uma das técnicas que mais denunciam a interferência na conotação da imagem. Isso demonstra preocupação ética; afinal, as imagens têm ponto de vista, mas não há uma tentativa de esconder isso através de manipulações digitais.

Porém, por mais que a fotografia tenha crescido em termos de liberdade e de aceitação de que ela é ponto de vista, ainda existem crenças fortemente enraizadas nos conceitos coletivos; os mesmos conceitos que separavam a arte da fotografia e que agora ainda relutam em permitir limites mais tênues entre a fotografia artística e o fotojornalismo. É claro, de uma fotografia jornalística se espera primeira e principalmente informação; mas após a análise que acaba de ser feita, acreditamos ser possível chegar a um ponto onde exista mais liberdade criativa sem a perda de informação e credibilidade no fotojornalismo, assim como ocorre em qualquer outra técnica do jornalismo; todas têm inerente a subjetividade característica do ser humano. Afinal, não somos máquinas; da pintura até a fotografia houve uma grande evolução tecnológica, mas o homem que comanda os pincéis, tintas, câmeras e botões, permanece, no âmago, o mesmo. Em busca de uma representação de si mesmo, a forma como vê as pessoas e o mundo, suas crenças, fé, esperanças. Uma representação particular, sua. A imagem fotográfica é indissociável de seu ato de criação, é ingenuidade vê-la de outra forma.

\section{Referências}

AUMONT, Jacques. A imagem. Campinas: Papirus, 1990.

BARTHES, Roland. O óbvio e o obtuso. Rio de Janeiro: Nova Fronteira, 1990.

DUBOIS, Philippe. O ato fotográfico e outros ensaios. Campinas: Papirus, 1993. 

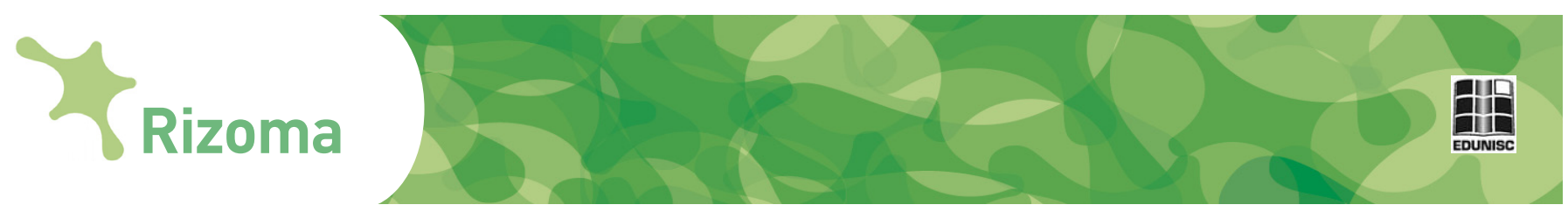

FLUSSER, Vilém. A filosofia da caixa preta: ensaios para uma futura filosofia da fotografia. Rio de Janeiro: Relume Dumará, 2002.

LOHMANN, R.; BARROS, A. T. M. P. A Objetividade no Fotojornalismo. In: XIII CONGRESSO DE CIÊNCIAS DA COMUNICAÇÃO NA REGIÃO SUL - CHAPECÓ, 2012, Santa Catarina. Anais eletrônicos... : Chapecó [s.n.], 2012. Disponível em: <http://www.intercom.org.br/ papers/regionais/sul2012/resumos/R30-1013-1.pdf>. Acesso em 21 jul. 2014.

MACHADO, Arlindo. A ilusão especular. São Paulo: Brasiliense, 1984.

OLIVEIRA, E. M. de; VICENTINI, A. Fotojornalismo: uma viagem entre o analógico e o digital. São Paulo; Cengage Learning, 2009.

TRAQUINA, Nelson. Teorias do Jornalismo: porque as notícias são como são. Florianópolis: Insular, 2004. 